\title{
Петрографическая и петрохимическая характеристика гнейсов и гранитоидов обрамления массива Ярва-варака
}

\author{
Сосновская М.А. ${ }^{1}$, Нерович Л.И. ${ }^{2}$ \\ ${ }^{1}$ Cтуудент АФ МГТУ, Anamumbl, margarita_margarita1@mail.ru \\ ${ }^{2}$ Геологический институт КНЦРАН,nerovich@geoks.apatity.ru,nikolaygroshev@gmail.com
}

Аннотация. В научной работе представлены данные петрографических и петрохимических исследований гнейсов и гранитоидов обрамления массива Ярва-варака. В обрамлении интрузива были подробно изучены глиноземистые гнейсы, гранитоиды а также жилы пегматитов. Среди гнейсов были выделены следующие разновидности: силлиманит-биотитовые гнейсы, гранат-биотитовые гнейсы, гранат-ставролит-биотитовые гнейсы, кианит-биотитовые гнейсы, амфибол-биотитовые гнейсы, эпидот-биотитовые гнейсы и биотитовые гнейсы. Гранитоиды чаще наблюдаются в виде тел, субсогласных со сланцеватостью гнейсов и секутся пегматитовыми жилами. Среди гранитоидов можно выделить следующие разновидности: биотитовые граниты, микроклиновые неравномерно гнейсовидные граниты, гранодиориты, два типа пегматитовых жил - аляскитовые пегматиты и плагиопегматиты, субщелочные двуполевошпатовые лейкограниты (монцолейкограниты). Изученные гранитоиды, за исключением плагиопегматитов, соответствуют корово-анатектическим образованиям. Все гнейсы имеют избыточное содержанием $\mathrm{Al}_{2} \mathrm{O}_{3}$ и соответствуют парапородам.

Ключевые слова: массив Явра-варака, гнейсы, гранитоиды, пегматиты.

\section{Petrographic and petrochemical characteristics of gneisses and granitoids of the rocks of the framing of the Jarva-varaka massif}

\author{
Sosnovskaya M.A. ${ }^{1}$, Nerovich L.I. ${ }^{2}$ \\ ${ }^{1}$ AS MSTU, Apatity, Russia \\ ${ }^{2}$ Geological Institute of Kola Scientific Centre of RAS, Apatity, Russia
}

\begin{abstract}
The scientific work presents data from petrographic and petrochemical studies of framing rocks and the Jarva-varaka massif. Alumina gneisses, granitoids, and also pegmatite veins were studied in details in the frame of the intrusion. Among the gneisses, the following varieties were distinguished: sillimanite-biotite gneisses, garnetbiotite gneisses. Garnet-staurolite-biotite gneisses, kyanite-biotite gneisses, amphibole-biotite gneisses, epidotebiotite gneisses and biotite gneisses. Granitoids are more often observed in the form of bodies subconsonant with shale gneiss and are split by pegmatite veins. Among the granitoids, the following varieties can be distinguished: biotite granites, microcline uneven gneiss-shaped granites, granodiorites, two types of pegmatite veins - alaskitic pegmatites and plagiopegmatites, subalkaline bicarbonate leucogranites (monzole granites). The studied granitoids, with the exception of plagiopegmatitis, correspond to cortical anatectic formations. All gneisses have excess $\mathrm{Al}_{2} \mathrm{O}_{3}$ content and correspond to para-rocks. Key words: Javra-varaka massif, gneiss, granitoids, pegmatites.
\end{abstract}

Key words: Jarva-varaka massif, gneisses, granitoids, pegmatites.

\section{Введение}

Массив Ярва-варака расположен в 12 км к северо-западу от г. Мончегорска и представляет собой интрузивное тело неправильной формы размером $1.7 \times 2.2$ км в плане и мощностью до 2 км. (Докучаева, Борисова, 1974; Расслоенные интрузии..., 2004). Массив сложен норитами двух типов, гиперстеновыми диоритами, пижонит-авгитовыми диоритами, кварцевыми диоритами и гранодиоритами. Во всех породах массива присутствует гранофир. Породы обрамления отличаются большим разнообразием гнейсов и гранитоидов. Также здесь присутствуют силлиманит-мусковитфлогопитовые сланцы из линз и прерывистых полос в тектонитах, сами тектониты с будинами и порфирокластами полевых шпатов и кварца, долериты. Наиболее своеобразной породой обрамления является псевдотахилитовая брекчия со стекловатым цементом и обломками. Данная работа посвящена петрографической и петрохимической характеристике гнейсов и гранитоидов. 


\section{Петрографическая характеристика гнейсов и гранитоидов}

По результатам петрографических исследований среди гнейсов были выделены следующие разновидности: силлиманит-биотитовые гнейсы, гранат-биотитовые гнейсы, гранат-ставролитбиотитовые гнейсы, кианит-биотитовые гнейсы, амфибол-биотитовые гнейсы, эпидот-биотитовые гнейсы и биотитовые гнейсы.
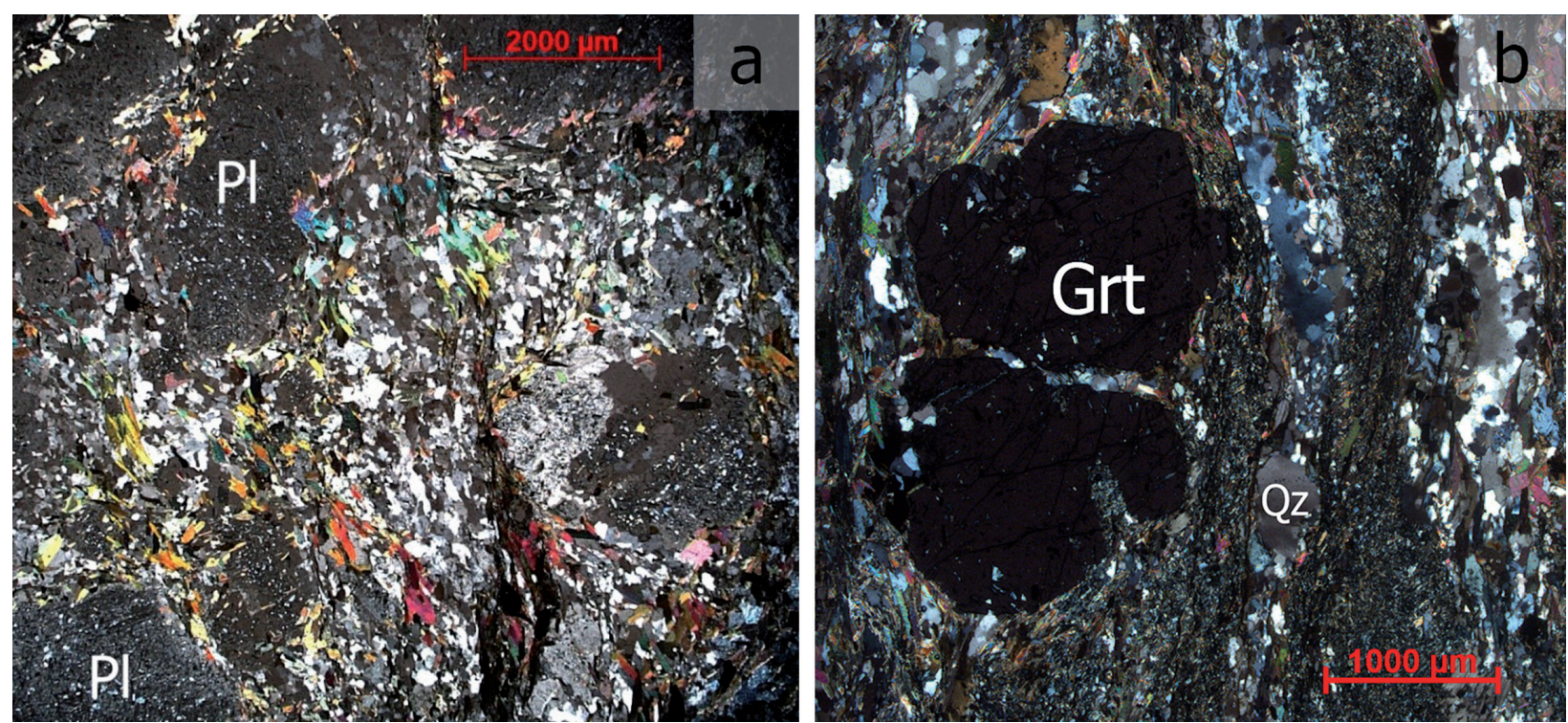

Рис. 1 C анализатором. а - порфирокластовая и лепидогранобластовая структура в амфибол биотитовом гнейсе. b - порфиробласт граната в гранат-ставролит-биотитовом гнейсе. Видны неправильные зёрна кварца.

Fig. 1 With analyzer. a - porphyroclastic and lepidogranoblast structure in amphibole biotite gneiss. $b$ - garnet porphyroblast in garnet-staurolite-biotite gneiss. Irregular quartz grains are visible.

В целом для гнейсов характерна сланцеватая текстура и лепидогранобластовая структура. Также среди изученных образцов встречаются разновидности как с порфирокластовой, так и с порфиробластовой структурой, при лепидогранобластовой структуре основной ткани породы. К разновидностям с порфирокластовой структурой относятся амфибол-биотитовые и эпидот-биотитовые гнейсы, где порфирокласты плагиоклаза погружены в основную цементирующую массу породы (рис. 1). Для этих пород характерны следующие содержания минералов: плагиоклаз (35-50 \%), кварц (25-30 \%), биотит (15-25 \%). В эпидот-биотитовом гнейсе содержание эпидота достигает $15 \%$. Акцессорными минералами являются титанит, рутил и рудный минерал. В амфибол-биотитовом гнейсе содержание амфибола обычно составляет 5 \%. Вторичные минералы представлены эпидотом, развивающимся по плагиоклазу порфирокластов. Акцессорным является рудный минерал.

Гранат-ставролит-биотитовые гнейсы характеризуются порфиробластовой структурой и лепидогранобластовой структурой основной ткани породы. Характерной чертой порфиробластовой структуры является присутствие порфиробластов граната (рис. 1). Порода состоит из биотита (20-40 \%), ставролита (10-30 \%), кварца (20-25\%), плагиоклаза (15-20\%), граната (5 \%), мусковита. Вторичные минералы представлены серицитом и хлоритом. Акцессорными минералами являются рутил и рудный минерал.

Кианит-биотитовый гнейс характеризуется сланцеватой, линзовидно-полосчатой текстурой и гломеролепидогранобластовой структурой обусловленной наличием относительно крупных линз, сложенных кварцем или плагиоклазом среди мелкозернистых минералов изометричной и пластинчатой формы, когда те и другие присутствуют в значительных количествах. Минеральный состав породы варьирует в следующих пределах: кварц (25-45 \%), плагиоклаз (5-20 \%), биотит (15-30 \%), кианит (15-30 \%), мусковит (<1\%). Вторичные минералы представлены серицитом (7 \%). Акцессорные минералы - рутил и рудный минерал. 


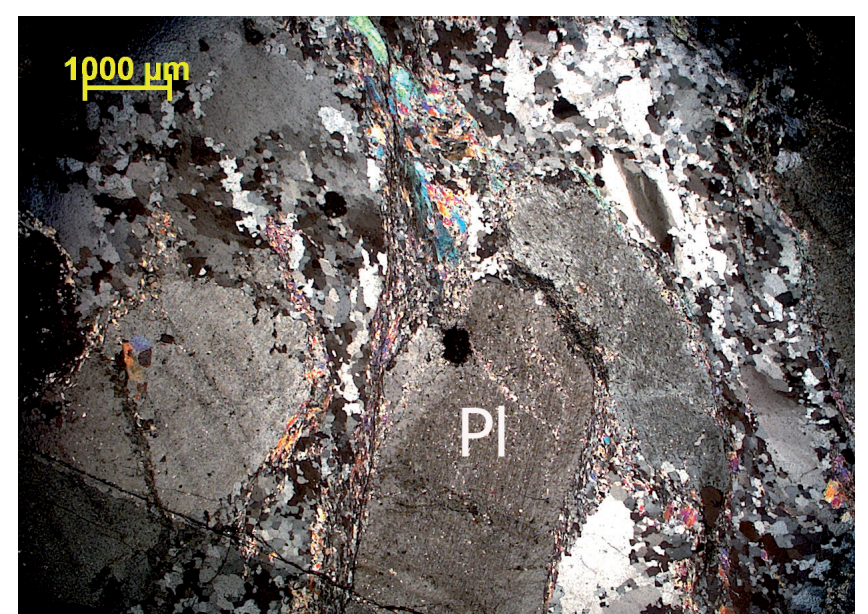

Рис. 2. С анализатором. Лейкоплагиогранит из будин в тектонитах. Порфирокластовая структура, где порфирокласты плагиоклаза погружённые в основную ткань породы.

Fig. 2. With an analyzer. Leukoplagiogranit from boudin in tectonites. Porphyroclast structure, where the plagioclase porphyroclasts are immersed in the main tissue of the rock.

Силлиманит-биотитовые гнейсы, гранат-биотитовые гнейсы и биотитовые гнейсы характеризуются лепидогранобластовой структурой. Породы состоят из плагиоклаза (30-50 \%), биотита (20-45 \%), кварца (10-30 \%). Для силлиманит-биотитового гнейса характерно присутствие фибролита до (5 \%), в гранат-биотитовом гнейсе присутствует гранат до (5 \%) Вторичные минералы представлены серицитом. Акцессорными минералами являются апатит, циркон и рудный минерал.

По результатам полевых и петрографических исследований среди гранитоидов были выделены следующие разновидности: лейкограниты мелких жил в гнейсах и будин в тектонитах; микроклиновые граниты, неравномерно гнейсовидные; биотитовые граниты субпластовых тел в гнейcax, субсогласных с гнейсовидностью вмещающих гнейсов; гранодиориты; аляскитовые пегматиты; плагиопегматиты.

Особенностью изученных гранитоидов является частая встречаемость порфирокластовой структуры. Она особенно характерна для гранитов мелких жил и будин из тектонитов и микроклиновых гранитов. Порфирокласты плагиоклаза и микроклина в этих породах погружены в более мелкозернистую раздробленную и перекристализованную массу (рис. 2). Также в гранитоидах распространена гипидиоморфнозернистая структура.

Среди биотитовых гранитов субпластовых и субсогласных со сланцеватостью в гнейсах тел выделяются 2 разновидности: с микроклином и с ортоклазом, присутствие которого подчеркивает-
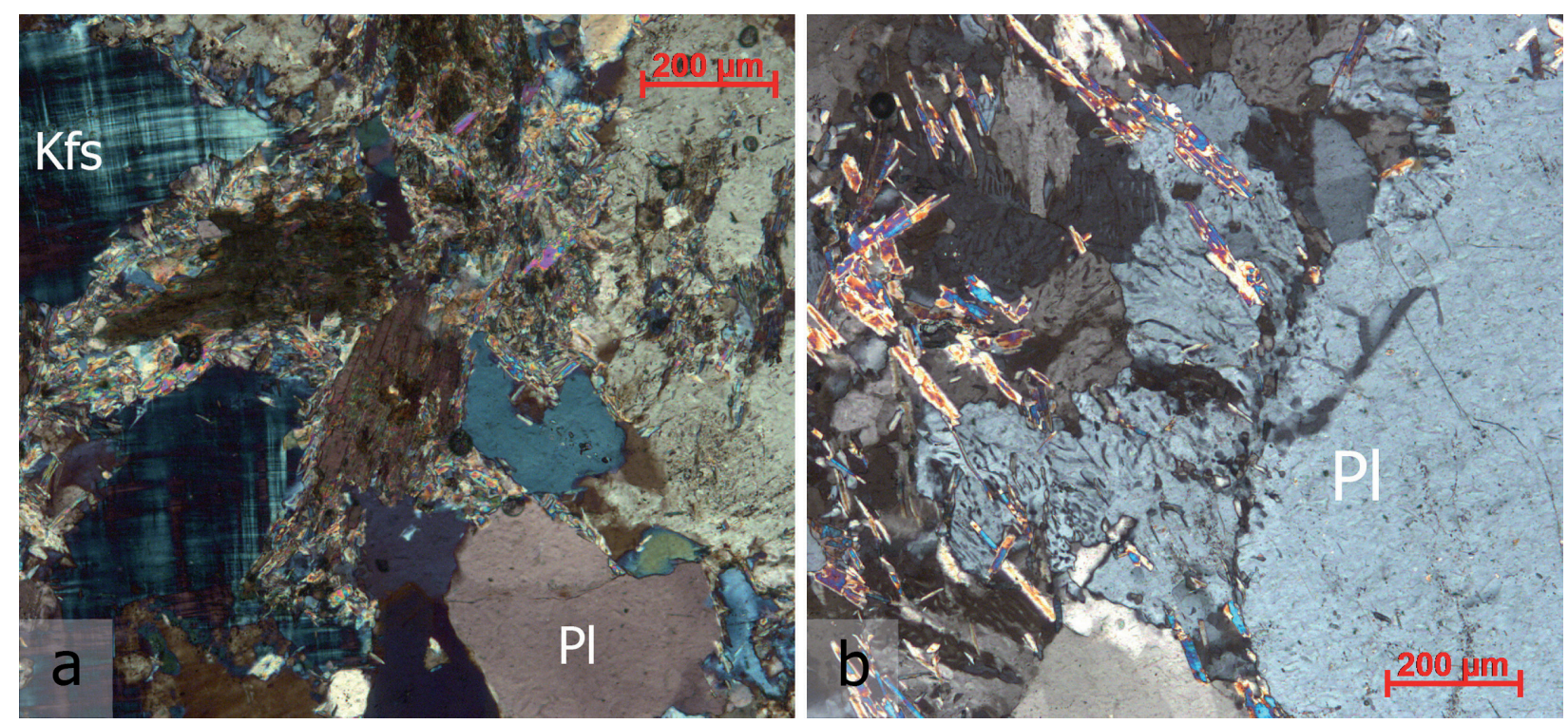

Рис. 3. С анализатором. a - биотитовый гранит с микроклином. Микроклин с отчётливой решёткой. $\mathrm{b}$ - биотитовый гранит с ортоклазом. Мирмекиты.

Fig. 3. With an analyzer. a - biotite granite with microcline. Microcline with distinct grid. $\mathrm{b}$ - biotite granite with orthoclase. Myrmekite. 
ся обилием в породе мирмекитов (рис. 3). В целом состав двух разновидностей практически аналогичен: плагиоклаз (30-40 \%), кварц (30-40 \%) биотит первой генерации (5\%), мусковит (5 \%). Отличаются породы присутствием в разновидности с микроклином - микроклина в количестве $(20 \%)$ и в таком же количестве ортоклаза в другой разновидности. Вторичными минералами являются биотит второй генерации и серицит. Акцессорными -циркон и рудный минерал. Субпластовые тела секутся жилами аляскитовых- и плагиопегматитов.

Биотитовые гранодиориты выделяются среди остальных гранитоидов более равномернозернистым строением и своеобразной структурой погасания биотита «kink banding» - полосы излома, похожие наблюдаются в гнейсах пород основания Садбери (French, 1998). Такой же биотит отмечается в гнейсах вблизи псевдотахилитовой брекчии.

\section{Петрохимическая характеристика гнейсов и гранитоидов}

Составы гнейсов, были пересчитаны для реконструкции их первичного состава с использованием диаграммы А.А. Предовского (Предовский, 1980). Согласно диаграмме первичной реконструкции F-A A.A. Предовского (рис. 4) все изученные образцы соответствуют парапородам, то есть это метаморфизованные осадочные породы. Наибольший разброс параметра А показывают биотитовые гнейсы. Соответственно среди них присутствуют разности, которые попадают как в область глинистых осадков (монтмориллонитовых глин), так и в область граувакк и смешанных продуктов выветривания основных и ультраосновных пород.

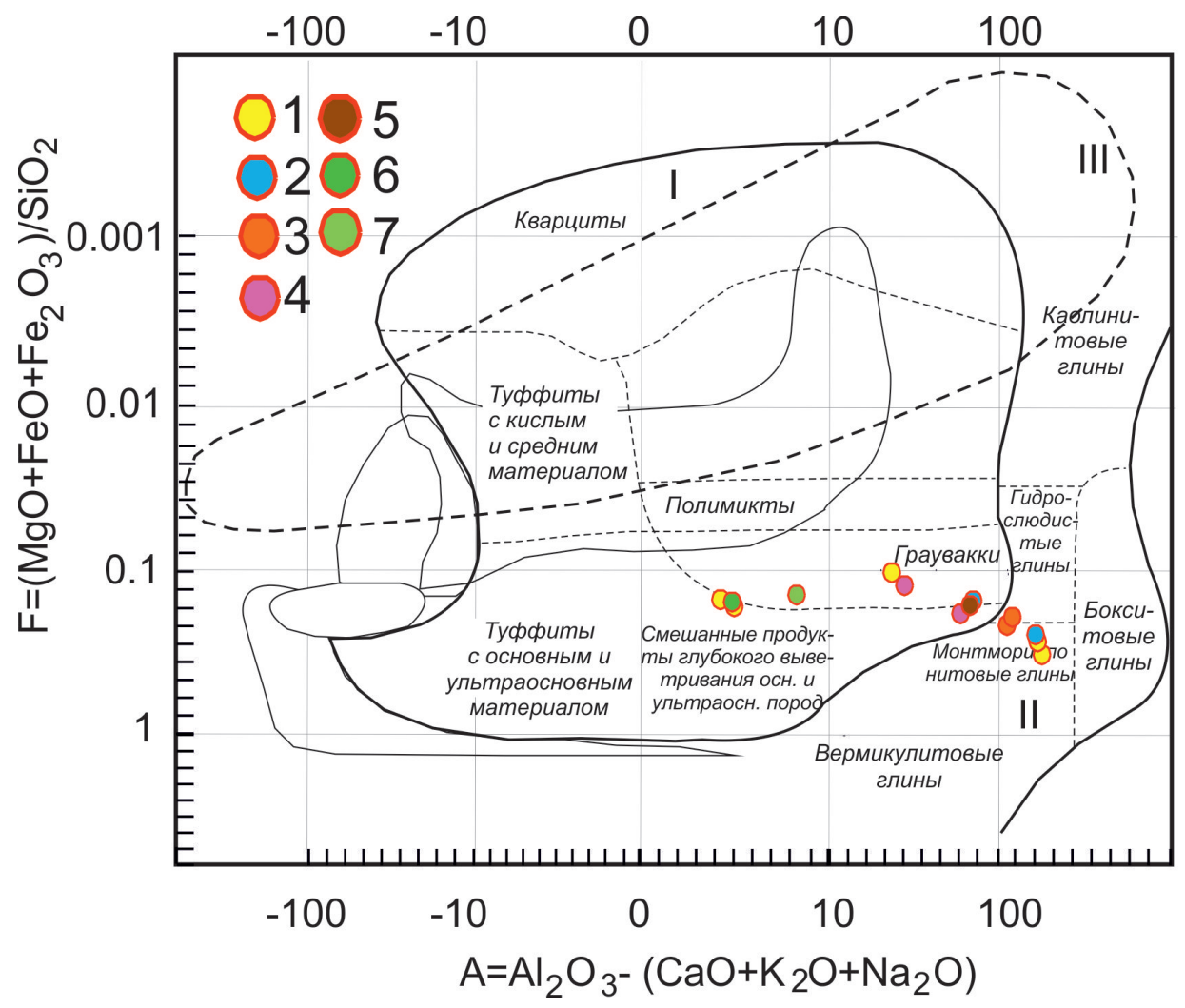

Рис. 4. Диаграмма F-A для реконструкции и сопоставления первичного состава силикатных вулканогенных, вулканогенно-осадочных и терригенно-осадочных пород по А.А. Предовскому (Предовский, 1980).

1 -биотитовые гнейсы, 2 -кианитовые гнейсы, 3 -гранат-ставролит-биотитовые гнейсы, 4-гранат-биотитовые гнейсы, 5 - силлиманит-биотитовый гнейс, 6 - амфибол-биотитовый гнейс, 7 - эпидот-биотитовый гнейс.

Fig. 4. F-A diagram for reconstruction and comparison of the primary composition of silicate volcanic, volcanicsedimentary and terrigenous-sedimentary rocks after [Predovsky, 1980].

1 - biotite gneisses; 2 - kyanite gneisses; 3 - garnet-staurolite-biotite gneisses; 4 - garnet-biotite gneisses; 5 - sillimanite-biotite gneiss; 6 - amphibole-biotite gneiss; 7 - epidote-biotite gneiss. 


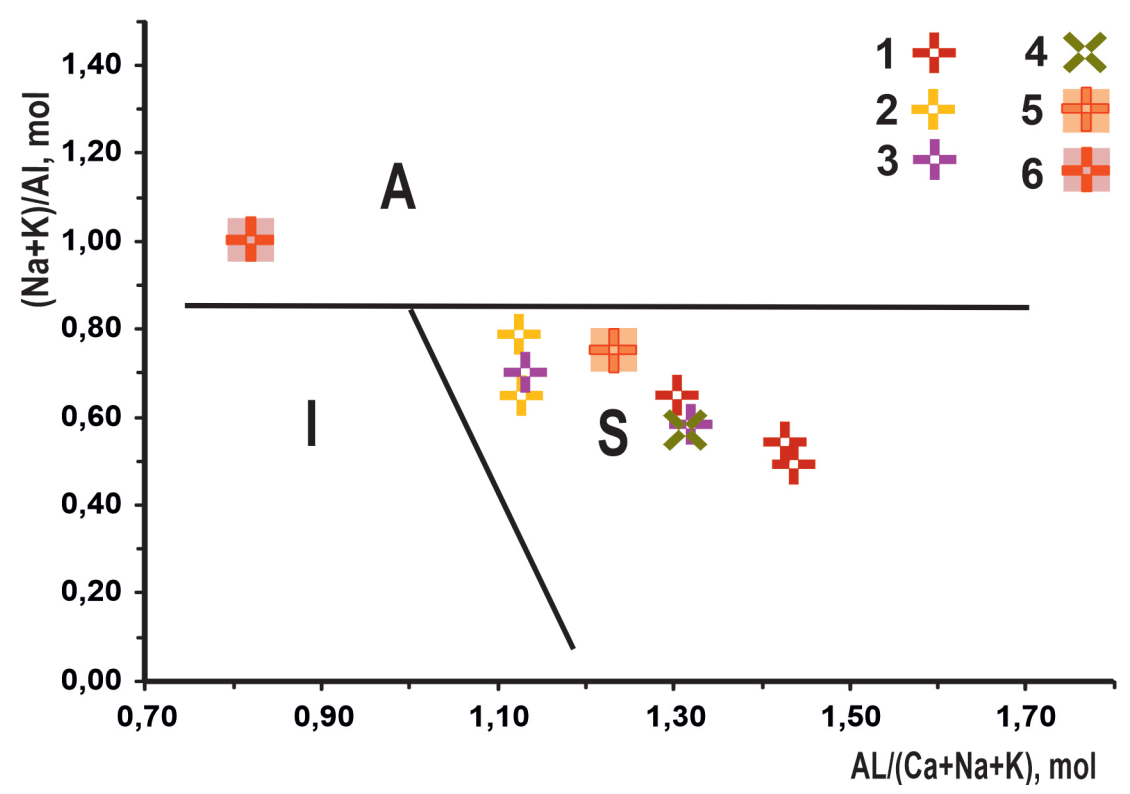

Рис. 5. Дискриминантная диаграмма $\mathrm{Al}_{2} \mathrm{O}_{3} /\left(\mathrm{CaO}+\mathrm{Na}_{2} \mathrm{O}+\mathrm{K}_{2} \mathrm{O}\right)-(\mathrm{Na}+\mathrm{K}) / \mathrm{Al}_{2} \mathrm{O}_{3}$ для гранитоидов обрамления массива Ярва-варака (Maeda, 1990).

1 - лейкограниты мелких жил в гнейсах и будин в тектонитах; 2 - микроклиновые граниты; 3 - биотитовые граниты субпластовых тел в гнейсах; 4 - гранодиориты; 5 - аляскитовый пегматит; 6 - плагиопегматит.

Fig. 5. The discriminant diagram $\mathrm{Al}_{2} \mathrm{O}_{3} /\left(\mathrm{CaO}+\mathrm{Na}_{2} \mathrm{O}+\mathrm{K}_{2} \mathrm{O}\right)-(\mathrm{Na}+\mathrm{K}) / \mathrm{Al}_{2} \mathrm{O}_{3}$ for the granitoids of the framing of the Jarva-varaka massif (Maeda, 1990).

1 - leucogranites of small veins in gneisses and boudins in tectonites; 2 - microcline granites; 3 - biotite granites of subplastic bodies in gneisses; 4 - granodiorites; 5 - alaskitic pegmatitis; 6 - plagiopegmatitis.

Химические анализы гранитоидов были пересчитаны для нанесения на дискриминантную диаграмму (Maeda, 1990) (рис. 5). Практически все изученные образцы гранитоидов попадают на диаграмме в поле $\mathrm{S}$ гранитов. В этом поле самые низкие значения параметра $\mathrm{Al}_{2} \mathrm{O}_{3} /\left(\mathrm{CaO}+\mathrm{K} 2 \mathrm{O}+\mathrm{Na}_{2} \mathrm{O}\right)$ характерны для микроклиновых гранитов и одного образца биотитового гранита. Остальные разности, а именно гранодиорит, биотитовый гранит и аляскитовый пегматит имеют более высокое значение данного параметра. Единственный образец плагиопегматита попадает в поле А гранитов. Тип S гранитоидов обычно рассматривают как корово-анатектические образования в зонах высокоградиентного метаморфизма в режиме сжатия. Петрохимический тип А гранитоидов соответствует области анорогенных внутриплитных гранитоидов. (Chappell, White, 1992; Maeda, 1990).

\section{Литература}

1. Докучаева В.С., Борисова В.В. К вопросу о геологии и петрографии массива Ярва-Варака (Мончегорский район) // Региональная геология, металлогения и геофизика. Апатиты. 1974. С. 82-87.

2. Предовский А.А. Реконструкция условий седиментогенеза и вулканизма раннего докембрия. Л. Изд-во: Наука. 1980. 152 с.

3. Расслоенные интрузии Мончегорского рудного района: петрология, оруденение, изотопия, глубинное строение (ред. Ф.П. Митрофанов, В.Ф. Смолькин). В 2 частях. Апатиты. Изд-во: КНЦ РАН. 2004.177 с.

4. Tolstikhin I., Tarakanov S., Gannibal M. Helium diffusivity and fluxes from a sedimentary basin (Permo-Carboniferous trough, Northern Switzerland) // Chemical Geology. 2018. 486. P. 40-49. DOI: 10.1016/j.chemgeo.2018.03.029.

5. Chappell B.W., White A.J.R. I- and S-type granites in the Lachlan Fold Belt // Transactions of the Royal Society of Edinburg: Earth Sciences. 1992. V. 83. P. 1-26.

6. French B.M. Traces of Catastrophe: A Handbook of Shock-Metamorphic Effects in Terrestrial Meteorite Impact Structures. LPI Contribution № 954, Lunar and Planetary Institute, Houston. 1998. 120 p.

7. Maeda J. Opening of the Kuril Basin deduced from the magmatic history of Central Hokkaido, North Japan. Tectonophysics. 1990. 174. P. 235-255. 